\title{
Influence of piston ring pack configuration on blowby and friction losses in a marine two-stroke engine
}

\begin{abstract}
In the paper a comprehensive model of a piston ring pack motion on an oil film has been presented. The local thickness of the oil film can be compared to height of the combined surface roughness of a cylinder liner and piston rings. Equations describing the mixed lubrication problem based on the empirical mathematical model formulated in works of Patir, Cheng and Greenwood, Tripp have been combined and used in this paper. In addition a model of gas flow through the labyrinth seal of piston rings has been developed. The main parts of the model and software have been experimentally verified abroad by the author at the marine engine designing centre.

For the selected two-stroke marine engine, the influence of the number of piston rings used and the type of the top ring lock (straight or overlapped) on blowby to piston underside and on friction losses of the piston-ring-cylinder (PRC) system have been investigated. The developed model and software can be useful for optimization of the PRC system design.
\end{abstract}

Key words: marine engines, piston rings, gas dynamics, hydrodynamic lubrication, mixed friction

\section{Introduction}

Piston rings are important part of internal combustion engines. Commonly a set of piston rings is used to form a dynamic gas seal between the piston and cylinder wall [5, $6,13]$. The sliding motion of the piston forms a thin oil film between the ring land and cylinder wall, which lubricates the sliding components $[2,4,11]$. The hydrodynamic force generated by this thin oil film is opposed by a combination of the gas pressure acting on the back side of each ring and the ring stiffness. Due to the dynamic nature of these forces, each individual ring is periodically compressed and extended as the piston runs through its cycle. The problem of studying this interaction is further complicated by the high temperatures involved, as these result in low oil viscosity and subsequently very low oil film thickness. The oil film is typically thick enough to expect the existence of mixed lubrication, so this phenomenon should also be taken into account $[2,7,8,12,13]$. The use of modern oil of low viscosity, working at a high temperature causes the existence of a very thin oil film thickness comparable to the value of the liner surface roughness. In such conditions, the possibility of direct contact between the ring and cylinder liner surface exists. Therefore the numerical simulation of these processes, which take place in a typical piston ring pack operation, is important from practical point of view.

The purpose of this paper is to present numerical calculations concerning an influence of the number of piston rings used and the type of the top ring lock (straight or overlapped) on blowby to piston underside and on friction power losses of the PRC system.

\section{Modelling of piston ring pack operation}

\subsection{Developed sub-models}

A combined model of piston rings operation has been developed. It consists of two main models: a) model of gas flow through the labyrinth seal piston-rings-cylinder (PRC), b) model of oil flow in the lubrication gap between the ring and cylinder liner. The two aforementioned models are coupled. In addition, sub-models of the following mechanical phenomena have been used: a contact of rough surfaces, an axial movement of rings within piston grooves and an elastic torsional deformation of piston rings. All the submodels are described in detail in publications [15-18] of the author. In this paper only the sub-models of gas flow [18] and mixed lubrication $[3,9,18]$ are shortly presented.

\subsection{Model of gas flow through the labyrinth seal of piston rings}

The gas flow model $[16,18]$ consists of several volume regions $\mathrm{V}_{1}, \mathrm{~V}_{2}, \ldots, \mathrm{V}_{9}$, which are connected by orifices with cross-section areas $A_{1}, A_{2}, \ldots, A_{12}$ (Fig. 3). The volumes $\mathrm{V}_{3}, \mathrm{~V}_{5}, \mathrm{~V}_{7}$ correspond to volumes between the piston rings, while volumes $\mathrm{V}_{2}, \mathrm{~V}_{4}, \mathrm{~V}_{6}, \mathrm{~V}_{8}$ correspond to groove volumes behind rings. Orifices with cross-section areas $\mathrm{A}_{1}, \mathrm{~A}_{4}$, $\mathrm{A}_{7}, \mathrm{~A}_{10}$ correspond to the ring end gaps, whereas orifices with cross-sections $A_{2}, A_{3}, A_{5}, A_{6}, A_{8}, A_{9}, A_{11}, A_{12}$ correspond to ring-side crevices.
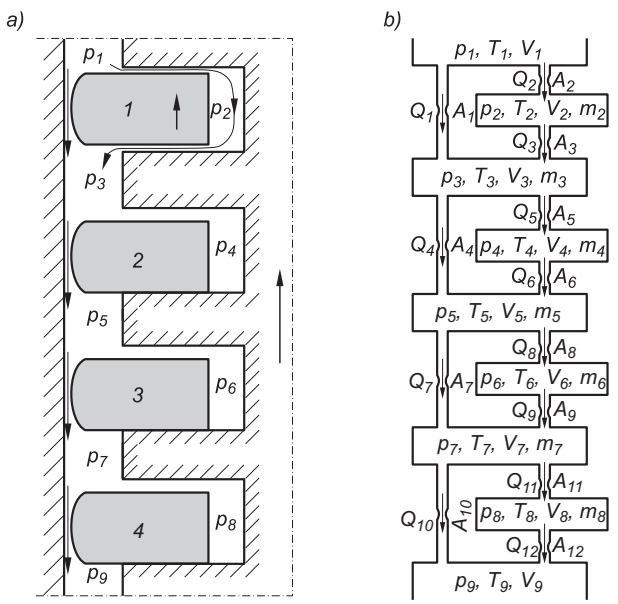

Fig. 1. Scheme of gas flow through the labyrinth seal of PRC system and the applied physical model for the ring pack of four piston rings

It was also assumed that the gas flow through orifices is isentropic (depending on pressure ratio - subsonic or sonic). The heat transfer between gas volume regions and surrounding walls was taken into account.

Thermal expansion of the piston and the cylinder liner and wear of the cylinder liner were taken into account. Leaks between piston rings and cylinder liner were defined 
by flow areas of ring end gaps, which depend on the position of the piston in cylinder.

In addition, mathematical description takes into account changes of gas volume regions and cross-section areas between the rings and the piston grooves (due to axial movement of the rings) $[5,6,13,18]$.

In the mathematical model of these phenomena equations of the following physical laws are utilized (here given for a gas volume number $k$ ):

Equation of mass balance:

$$
\mathrm{dm}_{\mathrm{k}}=\sum_{\mathrm{i}} \mathrm{dm}_{\mathrm{In}_{\mathrm{i}}}-\sum_{\mathrm{j}} \mathrm{dm}_{\mathrm{Out}_{\mathrm{j}}}
$$

Equation of energy balance:

$$
\begin{aligned}
& \sum_{\mathrm{i}} \mathrm{dm}_{\mathrm{In}_{\mathrm{i}}} \cdot \mathrm{i}_{\text {In }_{\mathrm{i}}}-\sum_{\mathrm{j}} \mathrm{dm}_{\text {Out }_{\mathrm{j}}} \cdot \mathrm{i}_{\text {Out }_{\mathrm{j}}}-\delta \mathrm{Q}_{\text {Wall }}= \\
& \mathrm{d}\left(\mathrm{m}_{\mathrm{k}} \cdot \mathrm{u}_{\mathrm{k}}\right)+\mathrm{p}_{\mathrm{k}} \cdot \mathrm{dV}_{\mathrm{k}}
\end{aligned}
$$

Gas state equation in differential form:

$$
\mathrm{dT}_{\mathrm{k}}=\mathrm{T}_{\mathrm{k}} \cdot\left(\frac{\mathrm{dp_{ \textrm {k } }}}{\mathrm{p}_{\mathrm{k}}}+\frac{\mathrm{dV}_{\mathrm{k}}}{\mathrm{V}_{\mathrm{k}}}-\frac{\mathrm{dm}_{\mathrm{k}}}{\mathrm{m}_{\mathrm{k}}}\right)
$$

where: $\mathrm{m}$ - gas mass, $\mathrm{p}$ - gas pressure, $\mathrm{T}$ - gas temperature, $\mathrm{u}$ - internal gas energy, $\mathrm{i}$ - gas enthalpy, $\mathrm{Q}$ - heat transferred through cylinder walls: index: In - gas inflow, Out gas outflow, $\mathrm{i}$ - number of inflow channel, $\mathrm{j}$ - number of outflow channel, $\mathrm{k}$ - number of gas volume.

\subsection{Model of oil flow in a gap (with rough surfaces) between the ring and cylinder}

Two main cases of oil flow in the system piston ring cylinder liner are presented in Fig. 4.

A one dimensional form of the modified Reynolds equation developed by Patir and Cheng [9] has been used to calculate hydrodynamic forces in the case of rough gap surfaces. This equation is applicable to any general roughness structure and takes the following form:
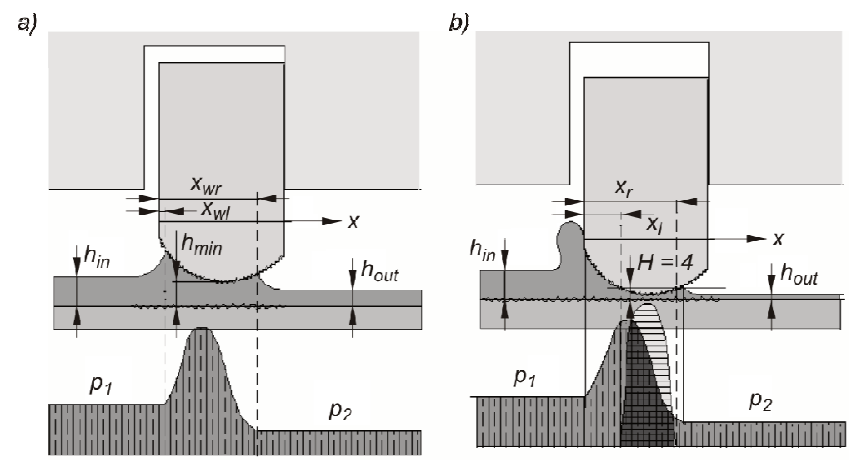

Fig. 2. Scheme of gap between the ring face and cylinder liner in the case of: a) fluid and b) mixed friction

A one dimensional form of the modified Reynolds equation developed by Patir and Cheng [9] has been used to calculate hydrodynamic forces in the case of rough gap surfaces. This equation is applicable to any general roughness structure and takes the following form:

$$
\frac{\partial}{\partial x}\left(\phi_{x} \frac{h^{3}}{12 \mu} \frac{d \bar{p}}{d x}\right)=\frac{U}{2} \frac{d \bar{h}_{T}}{d x}+\frac{U}{2} \sigma \frac{d \phi_{S}}{d x}+\frac{d \bar{h}_{T}}{d t}
$$

where: $\mathrm{t}$ - time; $\mathrm{x}$ - coordinate along cylinder liner; $\mathrm{h}$ nominal oil film thickness; $\mathrm{h}_{\mathrm{T}}-$ average gap (ringcylinder); $\mathrm{p}$ - hydrodynamic pressure; $\mathrm{U}$ - axial ring velocity; $\mu$-dynamic oil viscosity; $\mathrm{v}=\partial \mathrm{h}_{\mathrm{T}} / \partial \mathrm{t}-$ radial ring velocity, $\sigma-$ composite root mean square roughness of sliding surfaces.

The significance and mathematical description of empirical coefficients $\phi_{\mathrm{x}}, \phi_{\mathrm{S}}$ and boundary conditions of equation (4) are presented in [9] and also in [18].

The effects of interacting asperities of piston ring and cylinder liner surfaces were modelled using the mathematical model developed by Greenwood and Tripp [3]. In this case the asperity contact force per unit circumference is given by

$$
\mathrm{F}_{\mathrm{C}}=16 \sqrt{\frac{2}{15}} \pi(\eta \beta \sigma)^{2} \mathrm{E}^{\prime} \sqrt{\left(\frac{\sigma}{\beta}\right)} \int_{\mathrm{x}_{1}}^{\mathrm{x}_{\mathrm{r}}} \mathrm{F}_{5 / 2}\left(\frac{\mathrm{h}}{\sigma}\right) \mathrm{dx}
$$

where the integration limits $\mathrm{x}_{1}$ and $\mathrm{x}_{\mathrm{r}}$ define a continuous interval, $\mathrm{x}_{\mathrm{l}} \leq \mathrm{x} \leq \mathrm{x}_{\mathrm{r}}$ in which $\mathrm{h} / \sigma \leq 4$ and: $\mathrm{E}$ ' - composite elastic modulus (for cylinder liner and piston ring); $\eta-$ asperity density; $\beta$ - asperity radius of curvature; $\sigma-$ composite root mean square roughness of sliding surfaces.

The form of function $F_{5 / 2}$ can be found in article [3]. The model is also described in detail in publication [18] of the author of this article.

\section{Experimental verification of developed model}

A verification of the simulation model has been done by the author for a two- and four-stroke marine engine [15, 16, 18]. The experimental verification of the model of gas flow through the labyrinth seal of piston rings was carried out using measurements of unsteady gas pressure in the cylinder, between the piston rings and under piston performed by piezoelectric sensors mounted in the piston. A satisfactory qualitative and quantitative compatibility of the analyzed pressure variations has been achieved. The maximal relative differences between measured and calculated pressure values have not exceeded $15 \%[15,18]$. On the other hand, the experimental verification of the hydrodynamic model of piston rings involved measurement results of scraped oil volumes by a gland-box of a two-stroke marine engine. Unfortunately, similar measurements for piston ring packs of tested engines have not been carried out. Examination of scraped oil volumes by the ring pack (of the gland-box of marine internal combustion engine) proves a satisfactory quantitative agreement between numerical and experimental results. The maximal relative differences between measured and calculated values have not exceeded $10 \%$ $[15,18]$.

\section{Calculation results}

\subsection{Main data of chosen engine}

The computer program incorporating the presented model has been used for simulation of two-stroke Diesel engine (Tab. 1) operating at full load. The type of ring set 
considered is common in marine engines. The piston ring pack consists of four rings (Figs 1 and 3). The package includes conventional straight ring end gaps.

Table 1. Main data of the marine engine under consideration [14]

\begin{tabular}{|l|c|}
\hline Cylinder bore & $580 \mathrm{~mm}$ \\
\hline Piston stroke & $2416 \mathrm{~mm}$ \\
\hline Engine rotational speed & $105 \mathrm{rpm}$ \\
\hline
\end{tabular}

The surface geometry of the piston ring package, with vertical dimensions magnified by factor of 1000 relative to the horizontal ones, is depicted in Fig. 1. All the rings have the same asymmetrical barrel shape (Tab. 2).

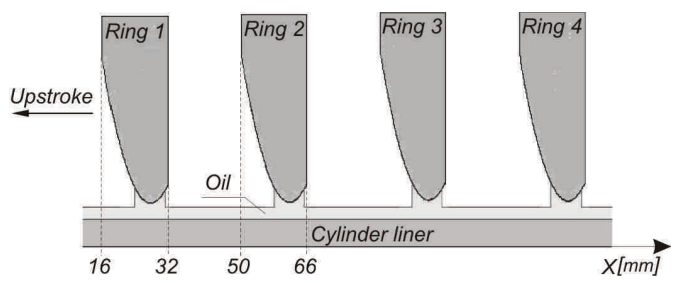

Fig. 3. Ring pack geometry under consideration

In order to ensure very low wear of profiled surfaces, the piston rings are coated (for example the top ring has chromium ceramic coating) $[1,10]$. As a consequence, even hydrodynamic conditions during a long period of piston rings operation can be ensured.

Table 2. Basic geometric parameters of piston rings: 1, 2, 3, 4

\begin{tabular}{|l|c|}
\hline Axial height of piston ring & $\mathrm{H}=16 \mathrm{~mm}$ \\
\hline Radius of parabolic sliding surface & $\mathrm{R}=750 \mathrm{~mm}$ \\
\hline Offset of parabolic sliding surface & $\mathrm{O}_{\mathrm{f}}=12 \mathrm{~mm}$ \\
\hline Distance between piston rings & $\mathrm{L}_{\mathrm{p}}=18 \mathrm{~mm}$ \\
\hline
\end{tabular}

\subsection{Calculation results for chosen types of the top ring}

The following two types of the top ring lock have been investigated (Fig 4): a) straight-cut (SC), b) gas-tight (GT) with overlapped joint.

a)
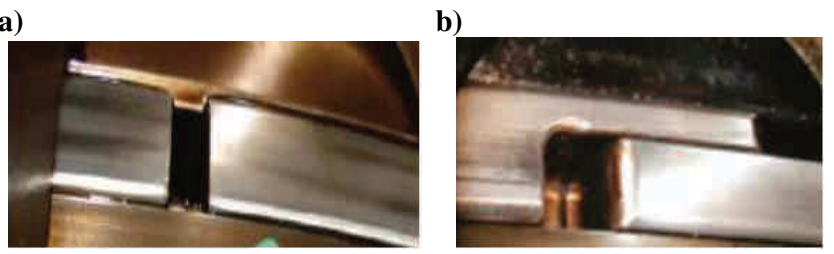

Fig. 4. Lock of the top piston ring: a) straight-cut (SC), b) gas-tight (GT) with overlapped joint (Copyright Winterthur Gas \& Diesel Ltd.)

In this subchapter two characteristic piston ring pack configurations have been analysed and compared. The first one indicated as $4 \mathrm{xSC}$ consists of 4 piston rings with straight-cut locks. The second one indicated as GT $+3 \mathrm{xSC}$ consist of gas-tight top ring (with overlapped joint) and 3 piston rings with straight-cut locks.

Typically, the figures that will follow show variation of some physical parameters as a function of the crankshaft rotation angle, beginning from the piston bottom dead centre $(\mathrm{BDC})$ of the two-stroke engine operation $\left(0^{\circ}\right)$. In this case the end of compression phase is at $180^{\circ}$ of crank angle (piston top dead centre - TDC). All the presented results correspond to full engine load.
In Fig. 5 calculated gas pressures $\boldsymbol{p}_{\boldsymbol{i}}(i=1,3,5,7)$ for the main volume regions of the labyrinth seal (Fig. 1) as a function of crank angle are shown. The first case corresponding to $4 \mathrm{xSC}$ piston ring pack configuration is presented in Fig. 5a, and the second one corresponding to GT $+3 x$ SC configuration is shown in Fig. 5b.

Figure 5 presents the pressure variation between piston rings, calculated on the basis of known cylinder pressure variation and simulated gas leakage through the labyrinth sealing of the piston ring pack (orifices corresponding to ring end gaps and ring-side crevices - Fig. 1). Generally, the gas pressure in the cylinder and all the inter-ring gas pressures increase during the piston upstroke (compression phase) and decrease during a certain part of the piston downstroke (expansion phase). In Fig. 5a the following maximum gas pressure values can be seen: nearly $16 \mathrm{MPa}$ in cylinder, over $8 \mathrm{MPa}$ between the $1^{\text {st }}$ and $2^{\text {nd }}$ piston ring, about $5 \mathrm{MPa}$ between the $2^{\text {nd }}$ and $3^{\text {rd }}$ ring and approximately $3 \mathrm{MPa}$ between the $3^{\text {rd }}$ and $4^{\text {th }}$ ring.

On the piston underside a relatively low scavenging air pressure is noticed. At the piston ring pack location near scavenging ports (i.e. between $300^{\circ}$ and $310^{\circ}$ of crank angle) all inter-ring gas pressures are visibly reduced.

a)

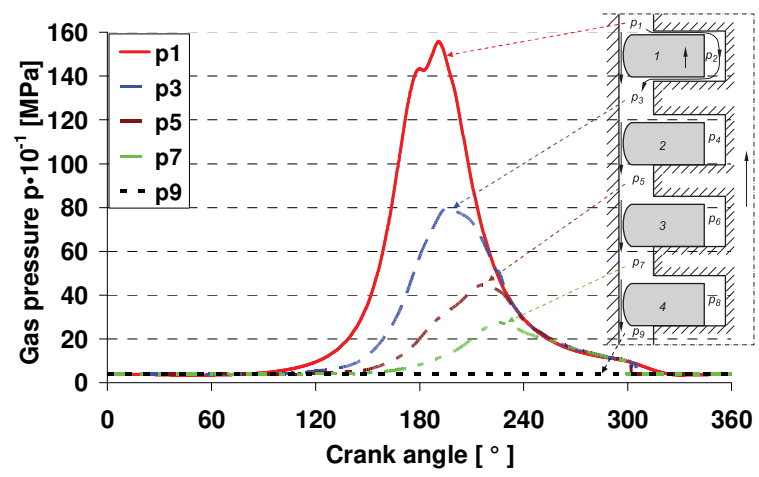

b)

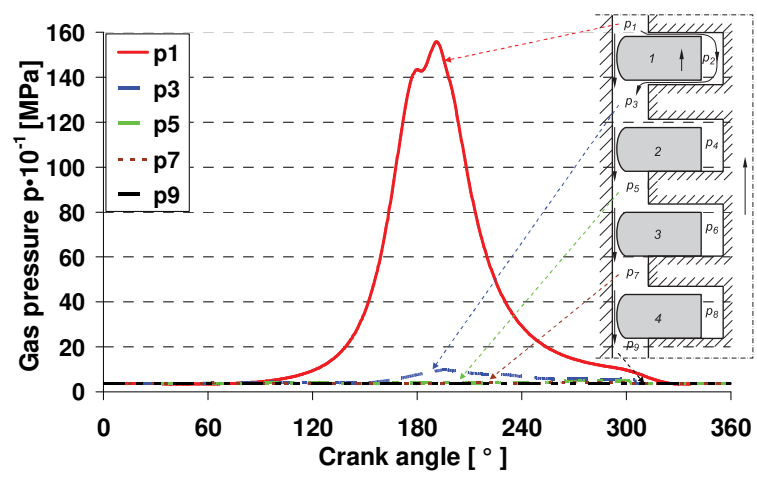

Fig. 5. Calculated gas pressure variations $\mathrm{p}_{\mathrm{i}}$ in all the volume regions versus crank angle. Gas pressure nomenclature: $p_{1}$ - in combustion chamber, $\mathrm{p}_{3}$ - between the $1^{\text {st }}$ and $2^{\text {nd }}$ piston ring, $\mathrm{p}_{5}$ - between the $2^{\text {nd }}$ and $3^{\text {rd }}$ piston ring, $\mathrm{p}_{7}-$ between the $3^{\text {rd }}$ and $4^{\text {th }}$ piston ring, $\mathrm{p}_{9}-$ under the piston. Piston ring pack configuration: a) $4 \mathrm{xSC}$, b) $\mathrm{GT}+3 \mathrm{xSC}$

Figure $5 \mathrm{~b}$ presents the calculation result corresponding to $\mathrm{GT}+3 \mathrm{xSC}$ piston ring pack configuration. Due to gastight top piston ring much higher pressure drop between the $1^{\text {st }}$ and $2^{\text {nd }}$ piston ring can be noticed. Gas pressure between the $1^{\text {st }}$ and $2^{\text {nd }}$ piston ring reaches the maximum value be- 
low $1 \mathrm{MPa}$. For this reason the $2^{\text {nd }}, 3^{\text {rd }}$ and $4^{\text {th }}$ piston ring are considerably less strongly pressed against the cylinder surface than in the case of the $4 \mathrm{xSC}$ configuration (compare Figs $5 \mathrm{a}$ and $5 \mathrm{~b}$ ). It should be noted that the top piston ring is not treated as quite gas-tight. It has been assumed that the leakage between the bottom side of this ring and the piston groove equals about $0.1 \%$ of the maximum possible axial ring lift. The mentioned leakage parameter has been evaluated during the verification of the gas flow model.

The hydrodynamic force acts in the radial direction on the ring and is counteracted by the spring force, gas force and friction force in the piston groove. The inertia force in the radial direction has been neglected due to very small values of the radial ring acceleration. Figure 6 presents the hydrodynamic force $F_{h}$ for each piston ring (Figs. 1 and 3) necessary for compensating both the gas pressure and radial forces resulting from the ring stiffness [18]. All the forces are referenced to unit circumference of the piston ring (unit forces $[\mathrm{N} / \mathrm{m}])$. The first case corresponding to $4 \mathrm{xSC}$ piston ring pack configuration is presented in Fig. $6 \mathrm{a}$, and the second one corresponding to GT $+3 \mathrm{xSC}$ configuration is shown in Fig. 6b. The variations of hydrodynamic forces look similar to variations of inter-ring gas pressures (compare Figs 5 and 6). First of all, the $1^{\text {st }}$ ring (top ring) is strongly pressed against the cylinder liner surface. The higher is the ring number (Figs 1 and 3), meaning more distant from the top, the less is the ring loaded. It should be added that hydrodynamic forces generated in oil gaps of the $2^{\text {nd }}, 3^{\text {rd }}$ and $4^{\text {th }}$ piston ring reach significantly less values than in the case of the $4 \mathrm{xSC}$ configuration (compare Figs. 6a and 6b).

a)

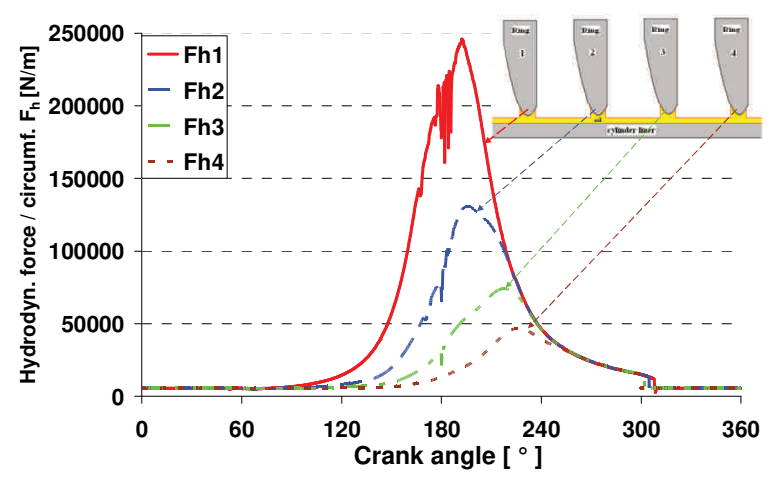

b)

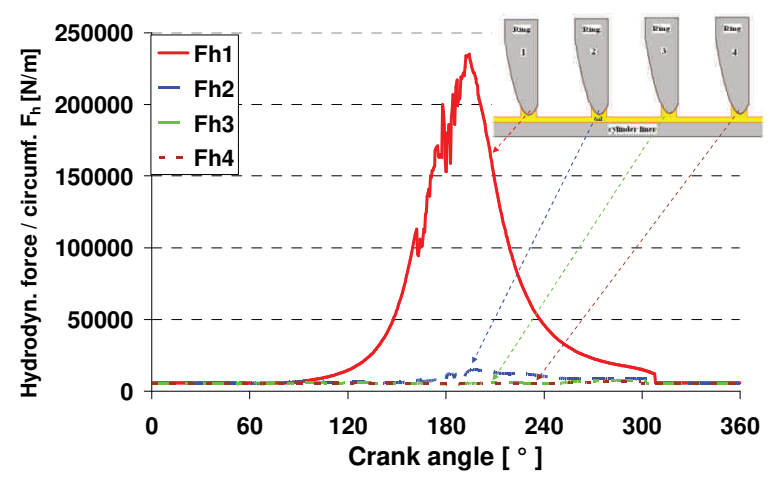

Fig. 6. Variation in hydrodynamic force $F_{h_{\_} i}$ generated by each piston ring (i - ring number) versus crank angle. Piston ring pack configuration: a) $4 \mathrm{xSC}$, b) GT+3xSC
Additionally, in the mixed lubrication cases the elastic radial contact forces are anticipated [18]. In Fig. 7 variations in aforementioned forces are shown. These forces occur in the case of a high gas pressure and low oil viscosity caused by high temperature near the top dead centre. It should be noticed that the values of elastic contact forces $F_{c}$ are much lower than hydrodynamic forces $F_{h}$ acting on rings (compare Figs 6 and 7).

The first case corresponding to $4 \mathrm{xSC}$ piston ring pack configuration is presented in Fig. 7a, and the second one corresponding to GT $+3 \mathrm{xSC}$ configuration is shown in Fig. 7b. In both cases the highest value of the contact force $F_{c}$ is generated by the $1^{\text {st }}$ ring (top ring). The higher is the ring number (Figs 1 and 3), the less is the radial contact force. It should be noted that these forces generated by the $2^{\text {nd }}, 3^{\text {rd }}$ and $4^{\text {th }}$ piston ring reach significantly less values than in the case of the $4 \mathrm{xSC}$ configuration (compare Figs $7 \mathrm{a}$ and $7 \mathrm{~b})$.

a)

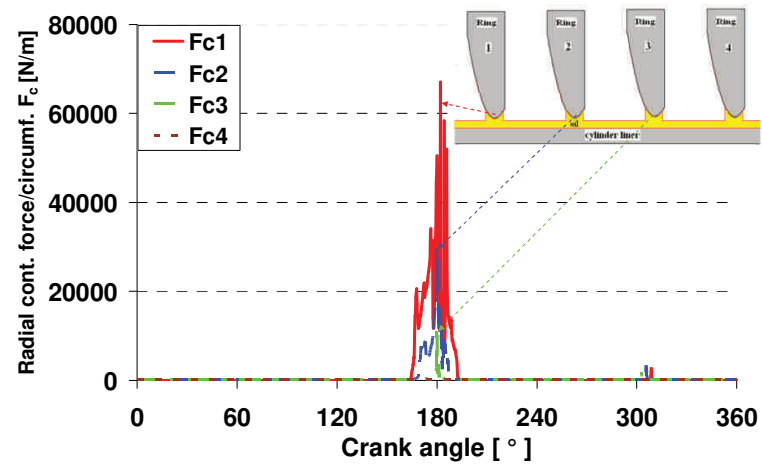

b)

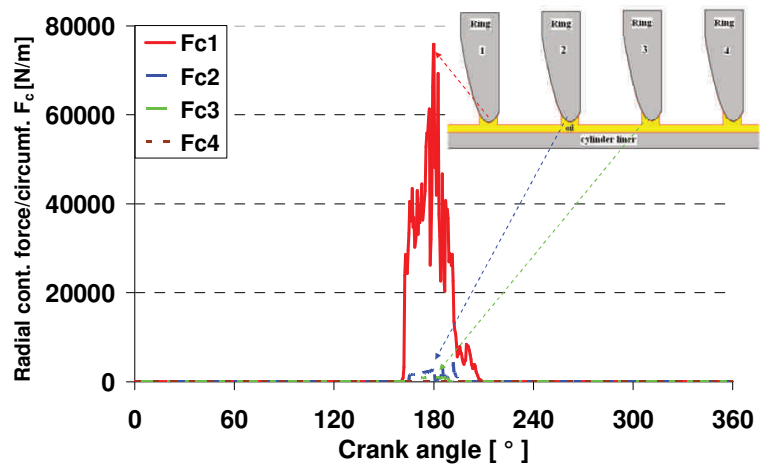

Fig. 7. Variation in radial component of contact force $F_{c \_i}$ for each piston ring ( $\mathrm{i}$ - ring number) versus crank angle. Piston ring pack configuration: a) $4 x S C$, b) GT $+3 x S C$

Analysing the presented results it can be concluded that hydrodynamic forces (Fig. 6) are generated by relatively low pressure acting on a large surface in contrast to high local contact pressure concentrated on a very small area of elastic contact (Fig. 7). Due to that the elastic contact seems to be responsible for the wear process.

Near the top dead centre (at high oil temperature) the additional tangential components of elastic contact forces (friction forces) $\mathrm{F}_{\mathrm{cx}}$ for each piston ring should be noticed (Fig. 8). But exactly at this piston reverse point the axial velocity of piston rings decreases to zero, which means the simultaneous drop of aforementioned forces to zero value. 
The sign change of these forces at TDC results from the sign change of piston velocity.

The first case corresponding to $4 \mathrm{xSC}$ piston ring pack configuration is presented in Fig. 8a, and the second one corresponding to $\mathrm{GT}+3 \mathrm{xSC}$ configuration is shown in Fig. 8 b. In both cases the highest value of the tangential contact force $\boldsymbol{F}_{\boldsymbol{c} x}$ is generated by the $1^{\text {st }}$ ring (top ring). The higher is the ring number (Figs 1 and 3), the less is the tangential contact force. It should be added that these forces generated by the $2^{\text {nd }}, 3^{\text {rd }}$ and $4^{\text {th }}$ piston ring reach significantly less values than in the case of the $4 \times$ SC configuration (compare Figs $8 \mathrm{a}$ and $8 \mathrm{~b}$ ).

a)

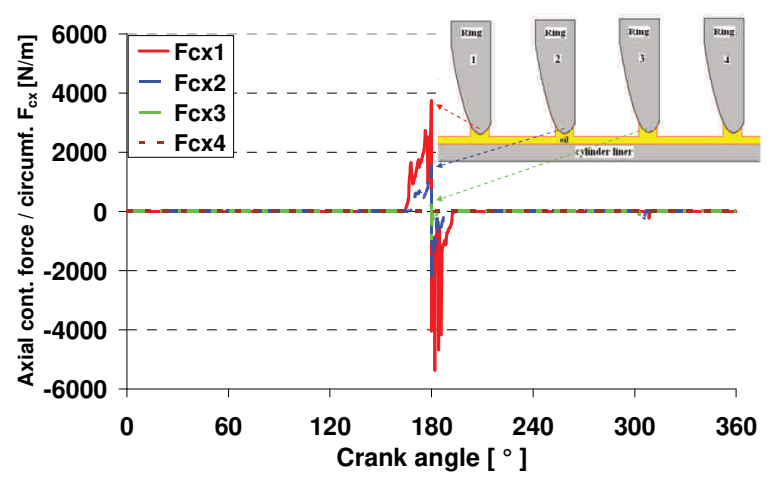

b)

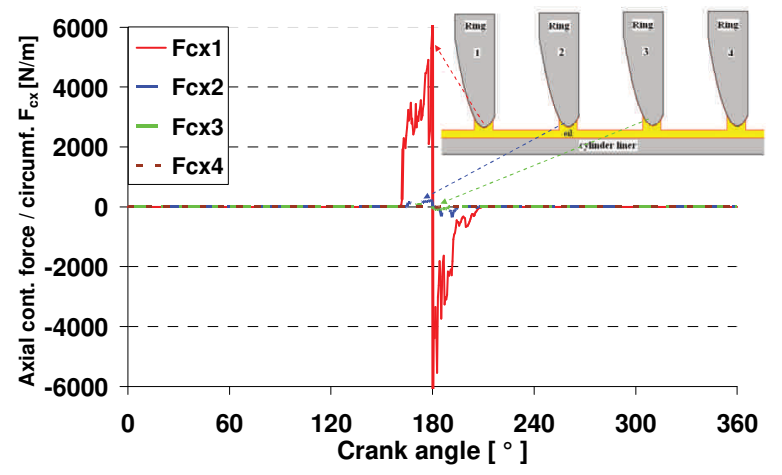

Fig. 8. Variation in tangential component of contact force $\mathrm{F}_{\mathrm{cx}_{\_} \mathrm{i}}$ for each piston ring ( $\mathrm{i}-$ ring number) versus crank angle. Piston ring pack configuration: a) $4 \times \mathrm{SC}$, b) $\mathrm{GT}+3 \mathrm{xSC}$

The motion of the ring pack scraping and distributing oil on the cylinder liner leaves the oil film profile shown in Fig. 9. This profile is formed after a few cycles of operation. An uneven oil film distribution along the cylinder liner can be clearly seen. Low film thickness near TDC and in the other part of cylinder liner at the location of scavenging air ports should be noticed. The minimum oil film thickness at TDC is about $0.2-0.3 \mu \mathrm{m}$ and is comparable with root mean square (RMS) roughness of the cylinder liner that equals $0.22 \mu \mathrm{m}$ [18]. The very low local film thickness values near TDC can be explained by occurrence of high gas pressure and high temperature in this area during the compression and working phases of engine operation. Due to high gas forces piston rings are strongly pressed against the cylinder surface. On the other hand, high temperature reduces the oil viscosity.

There are two places of oil supply for the cylinder liner of long-stroke IC engine located below TDC. Two peaks of oil film thickness at these places can be clearly seen in Fig. 9.

In a marine two-stroke engine the location of scavenging air ports is also important for cylinder lubrication. Their presence simply reduces the area of the mating surface between piston rings and cylinder liner. In this area a simplified approach was applied. The oil film thickness was assumed to be reduced at this location reflecting the reduced sliding surface.

Due to low gas pressure and oil temperature the greatest oil film thickness can be seen between scavenging air ports and the bottom dead centre (BDC).

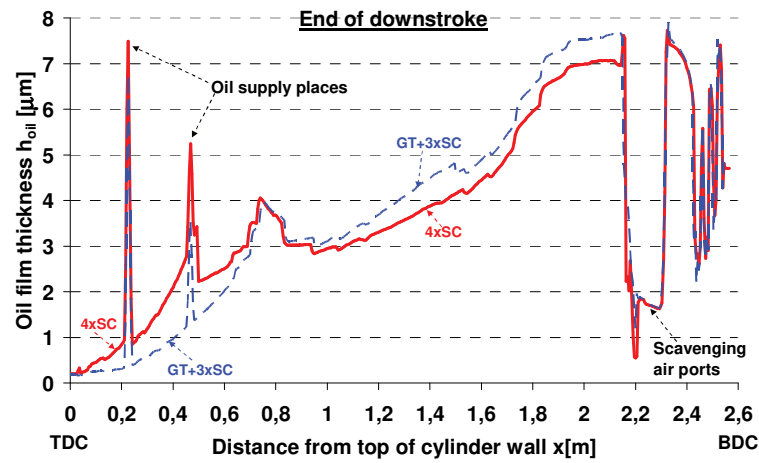

Fig. 9. Comparison of the oil film thickness $\mathrm{h}_{\text {oil }}$ left by the ring pack along cylinder wall concerning piston ring pack configurations $4 \mathrm{xSC}$ and GT $+3 x S C$

Near the piston top dead centre (TDC) a considerably bigger oil film thickness is noticed in the case of the ring pack configuration indicated as $4 \mathrm{xSC}$ than in the case of $\mathrm{GT}+3 \mathrm{xSC}$ configuration. For this reason the lubrication conditions near TDC are better in the first case. Therefore lower value of the tangential contact force $F_{c x}$ is generated by the top ring (compare Figs $8 \mathrm{a}$ and $8 \mathrm{~b}$ ).

But from the middle of the cylinder wall to the location of scavenging air ports an opposite situation is observed, i.e. lower oil film thickness is noticed in the case of $4 \mathrm{xSC}$ ring pack configuration than in the case of $\mathrm{GT}+3 \mathrm{xSC}$ configuration (Fig. 9).

\subsection{Calculation results for chosen piston ring pack configurations}

Complementary another four piston ring pack configurations have been analysed and compared with those described in the previous chapter (i.e. $4 \mathrm{xSC}$ and GT+3xSC). The total number of piston rings has been reduced to 2 or 3 , but in a real engine less than 3 rings have not been used. Firstly, two configurations of piston rings with all straightcut locks indicated as $2 \mathrm{xSC}$ and $3 \mathrm{xSC}$ have been taken into account. Secondly, two configurations with gas-tight top ring and 1 or 2 piston rings with straight-cut locks indicated as GT+SC and GT+2xSC have been analysed.

Multiplying friction forces (due to hydrodynamic and mixed lubrication) of all the rings by piston velocity, friction power losses can be calculated. In Fig 10 a comparison of results concerning mean values of total power losses for all the aforementioned piston ring pack configurations is shown. It should be noted that in any case the application of gas-tight top ring causes a certain increase of friction power 
loss compared with the use of the top ring with straight-cut lock. In addition, the larger the number of piston rings the greater the friction power loss can be noticed.

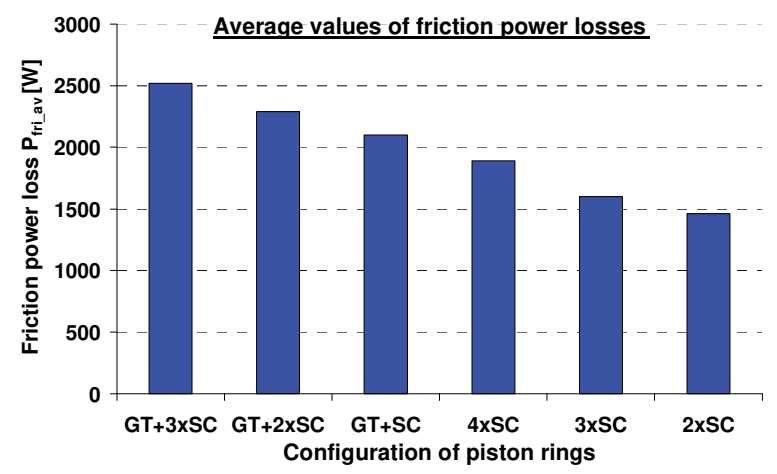

Fig. 10. Average values of total power loss $\mathbf{P}_{\text {fri_av }}$ (due to hydrodynamic and mixed lubrication) for different piston ring pack configurations.

Lock of the top piston ring: SC - straight-cut, GT - gas-tight

Then a comparison of gas blowby into piston underside for different piston ring pack configurations is shown (Fig. 11). It can be concluded that in any case the application of gas-tight top ring (configurations: GT+SC, $\mathrm{GT}+2 \mathrm{xSC}, \mathrm{GT}+3 \mathrm{xSC}$ ) causes an appreciable reduction of blow-down compared with the use of the top ring with straight-cut lock (configurations: $2 x \mathrm{SC}, 3 \mathrm{xSC}, 4 \mathrm{xSC}$ ). Consequently improved fuel efficiency can be expected. The greater the number of piston rings the lower the blow-down can be noticed for the configurations of piston rings with all straight-cut locks. In the case of configurations with gastight top ring $(\mathrm{GT}+\mathrm{SC}, \mathrm{GT}+2 \mathrm{xSC}, \mathrm{GT}+3 \mathrm{xSC})$, the gas blowby into piston underside is almost not influenced by the number of conventional piston rings with straight-cut locks. These rings are simply slightly pressed by the gas forces against the cylinder surface (Fig. 6b).

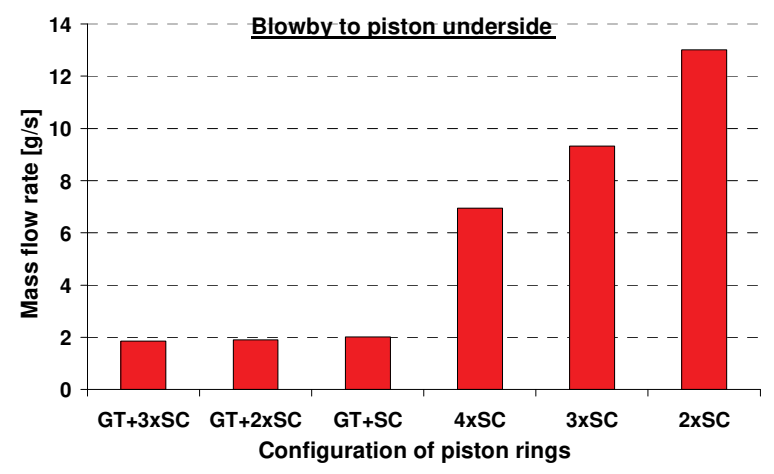

Fig. 11. Comparison of blowby for different ring pack configurations Lock of the top piston ring: SC - straight-cut, GT - gas-tight

\section{Conclusions}

The major conclusions that may be drawn from the results are as follows:

1. The developed mathematical model and simulation programme give a lot of practical information that would be more complicated and expensive to obtain using experimental methods.

2. At first two characteristic piston ring pack configurations indicated as $4 \mathrm{xSC}$ and GT $+3 \mathrm{xSC}$ have been compared. If the gas-tight (GT) top ring is applied (instead of the SC ring) then the following main phenomena can be noticed:

- much higher pressure drop between the $1^{\text {st }}$ and $2^{\text {nd }}$ piston ring (Fig. 5), and consequently the $2^{\text {nd }}, 3^{\text {rd }}$ and $4^{\text {th }}$ piston ring are significantly less strongly pressed against the cylinder surface (Fig. 6),

- higher radial and tangential components of elastic contact force acting on the top piston ring (Figs. $7,8)$,

- significantly lower radial and tangential components of elastic contact force acting on the $2^{\text {nd }}, 3^{\text {rd }}$ and $4^{\text {th }}$ piston ring (Figs. 7, 8),

- slightly lower oil film thickness near the piston top dead centre (TDC) and an opposite situation from the middle of the cylinder liner to the location of scavenging air ports (Fig. 9),

- more friction power loss of the piston ring pack (Fig. 10), but appreciable reduction of gas blowby to the piston underside (Fig. 11).

3 . In addition four piston ring pack configurations indicated as $2 \mathrm{xSC}, 3 \mathrm{xSC}, \mathrm{GT}+\mathrm{SC}$ and GT $+2 \mathrm{xSC}$ have been analysed. In mentioned cases the following phenomena can be observed:

- the greater the number of piston rings the more friction power loss (Fig. 10), but the lower the blowdown for configurations of piston rings with all straight-cut locks (Fig. 11),

- in the case of configurations GT+SC, GT $+2 x S C$ and $\mathrm{GT}+3 \mathrm{xSC}$, the gas blow-down is almost not influenced by the number of SC piston rings (Fig. 11).

4. The main aim of simulation of piston rings operation is to predict lubrication conditions, define areas of the possible cylinder liner wear and finally determine the gas leakage through the sealing ring set. Further investigation of these phenomena should be recommended.

\section{Acknowledgements}

The author expresses his gratitude to Wärtsilä's R\&D engine centre (nowadays: Winterthur Gas \& Diesel Ltd.) in Winterthur (Switzerland) for having the opportunity to work on projects concerning mathematical modelling and numerical simulation of tribological systems of piston rings during several research periods at this company.

\section{Abbreviations}

PRC piston-ring-cylinder

SC straight-cut lock of piston ring

GT gas-tight lock of top piston ring (overlapped joint)
TDC top dead centre

BDC bottom dead centre

RMS root mean square 


\section{Bibliography}

[1] DEMMERLE, R., BARROW, S., TERRETTAZ, F., JAQUET, D. New insights into the piston running behaviour of "Sulzer" large bore diesel engines. CIMAC Congress. 2001, Hamburg.

[2] DOWSON, D. Piston assemblies; background and lubrication analysis, engine tribology. Taylor C.M. (editor). Elsevier Science. 1993, 213-240.

[3] GREENWOOD, J., TRIPP, J.H. The contact of two nominally flat rough surfaces. Proc Inst. Mech. Eng. 1971, 185, 625-633.

[4] ISKRA, A. Parametry filmu olejowego w węzłach mechanizmu tłokowo-korbowego silnika spalinowego. Poznań. Wydawnictwo Politechniki Poznańskiej, 2001.

[5] KOSZAŁKA, G. Application of the piston-rings-cylinder kit model in the evaluation of operational changes in blowby flow rate. Eksploatacja $i$ Niezawodność - Maintenance and Reliability. 2010, 4, 72-81.

[6] KOSZAŁKA, G., GUZIK, M. Mathematical model of piston ring sealing in combustion engine. Polish Maritime Research. 2014, 4(84), 66-78.

[7] LIVANOS, G.A., KYRTATOS, N.P. Friction model of a marine diesel engine piston assembly. Tribology International. 2007, 40, 1441-1453.

[8] OFFNER, G. Friction power loss simulation of internal combustion engines considering mixed lubricated radial slider, axial slider and piston to liner contacts. Tribology Transactions. 2013, 56(3), 503-515.

[9] PATIR, N., CHENG, H.S. Application of average flow model to lubrication between rough sliding surfaces. Transactions of ASME. 1979, 101.

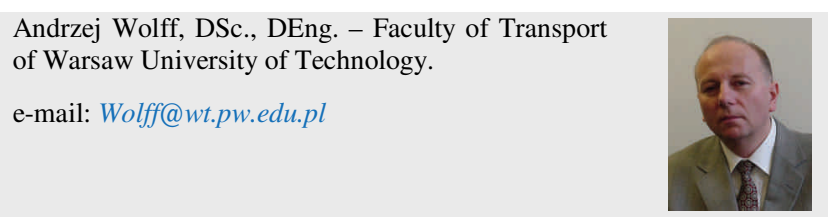

[10] RÄSS, K., AMOSER, M. Progressive development of twostroke engine tribology. CIMAC Congress. 2007, 83, Vienna.

[11] SERDECKI, W. Badania współpracy elementów układu tłokowo-cylindrowego silnika spalinowego. Wydawnictwo Politechniki Poznańskiej. Poznań 2002.

[12] TAMMINEN, J., SANDSTRÖM, C.-E., ANDERSSON, P. Influence of load on the tribological conditions in piston ring and cylinder liner contacts in a medium-speed diesel engine. Tribology International. 2006, 39, 1643-1652.

[13] TIAN, T. Dynamic behaviors of piston rings and their practical impact - part II: oil transport, friction, and wear of ring/liner interface and the effects of piston and ring dynamics. Proc. I. Mech. E, Part J: Journal of Engineering Tribology. 2002, 216, 229-247.

[14] Wärtsilä Technology Review, information materials concerning IC engines designed at Wärtsilä company.

[15] WOLFF, A. Experimental verification of the model of piston ring pack operation of an internal combustion engine. The Archive of Mechanical Engineering. 2009, LVI(1), 7390.

[16] WOLFF, A. Numerical analysis of piston ring pack operation of a marine two-stroke engine. Combustion Engines. 2011, 146(3).

[17] WOLFF, A. Influence of engine load on piston ring pack operation of a marine two-stroke engine. Journal of KONES Powertrain and Transport. 2012, 19(2), 557-569.

[18] WOLFF, A. Simulation based study of the system pistonring-cylinder of a marine two-stroke engine. Tribology Transactions. 2014, 57(4), 653-667. 